\title{
Possible mechanisms of chronic leprosy-related arthritis
}

\begin{abstract}
Microbial agents induce arthritis through mechanisms such as direct infiltration of tissue and by inducing autoimmune phenomena. The mechanisms involved in this last type of arthritis have been investigated. In experimental models of adjuvant and reactive arthritis, the involvement of $\mathrm{T}$ cells and in some cases mycobacteria in the development of arthritis have been confirmed. Cross-reactivity between the $65 \mathrm{kD}$ mycobacterial protein and cartilage proteoglycans has been postulated as a possible mechanism. In this study, chronic peripheral arthritis was observed in patients with Hansen's disease, in patients with resolved Hansen's and in those with paucibacillary forms. This arthritis was not related to reactional states (erythema nodosum leprosum and reversal reaction), in contrast to several reports in the literature. The mechanisms by which microbes could induce chronic arthritis are discussed herein.
\end{abstract}

UNITERMS: Mycobacteria, cellular immunity, humoral immunity, leprosy arthritis.

$\mathrm{E}$ xperimental models have suggested that mycobacterial infections can trigger autoimmune arthritis, mainly through T-cell mediated responses. Adjuvant arthritis, experimentally induced in rats by the intradermal injection of dead mycobacteria $(M$. tuberculosis) suspended in mineral oil, produces chronic inflammation of the articulations in genetically predisposed animals. ${ }^{\prime}$ In humans, arthritis has been reported in patients submitted to immunotherapy with BCG. $^{2}$

The role of mycobacteria in the pathogenesis of rheumatoid arthritis and other types of chronic inflammation has been suggested previously. ${ }^{3}$ In particular, mycobacterial heat-shock proteins have been considered important targets of the cellular immune response in patients with juvenile arthritis, ${ }^{4}$ rheumatoid arthritis, ${ }^{5}$ and of antibody production in rheumatoid arthritis patients. ${ }^{6}$ The $65 \mathrm{kD}$ heat-shock protein is an important target for arthritogenic T-cell clones, mainly the aminoacid sequence 180-188.

Peripheral blood and synovial fluid T-lymphocytes from patients with rheumatoid arthritis showed increased reactivity to a mycobacterial fraction that cross-reacted

\author{
Address for correspondence: \\ Waldenise Cossermelli-Messina \\ Av. Dr. Arnaldo, 455 - $3^{\circ}$ andar Reumatologia \\ São Paulo/SP - Brasil - CEP: 01246-903
}

with articular cartilage constituents, especially in patients with 1-10 years of disease duration. ${ }^{8}$ The response was considered specific since there was no reactivity to other mitogens or streptococcal antigens, suggesting a direct relationship between the mycobacterial antigens and the pathogenesis of rheumatoid arthritis.

Alteration in the agalactosyl immunoglobulin G (IgG) molecule was observed in patients with tuberculosis, erythema nodosum leprosum, ${ }^{9}$ Crohn's disease, and rheumatoid arthritis. ${ }^{10}$ Agalactosyl $\mathrm{IgG}$ is associated with cytokine production, acute phase response and tissue injury. ${ }^{10}$ Elevation of this immunoglobulin parallels with increased binding of mycobacterial proteins to immunoglobulins."

Chronic arthritis has been described in Hansen's disease but not associated with the presence of bacilli within the joint or to reactional states. ${ }^{12.13 .14}$ In a previous study by our group, ${ }^{15}$ peripheral arthritis was observed in several patients with Hansen's disease. In the majority, the arthritis followed a chronic pattern and was not associated with leprosy reactions. Arthritis was identified in patients with negative bacilloscopy and with resolved Hansen's disease. Patients with different forms of Hansen's disease (indeterminate, dimorphous, tuberculoid and lepromatous) had arthritis. These data contrasted with studies where arthritis was related and confined to erythema nodosum reactions.

We hypothesized the possible mechanisms involved in the generation of arthritis in patients with paucibacillary 
forms, with resolved Hansen's disease and without reaction. In addition, the long duration of the articular manifestation suggested that somehow it has been perpetuated.

Pathogenic mechanisms similar to those of adjuvant arthritis may be involved in the chronic articular phenomena in Hansen's disease, particularly if the homology between $\underline{M}$. leprae and $\underline{M}$. tuberculosis is considered. In adjuvant arthritis, the cellular immune response to mycobacterial antigens has been detected, and is probably involved in the development of arthritis. ${ }^{16}$ The identification of the $65 \mathrm{kDa}$ protein as the main target of T-cell mediated responses, ${ }^{17.18}$ its cross-reactivity to purified cartilage proteoglycans, ${ }^{19}$ including in rheumatoid arthritis, ${ }^{20}$ has emphasized its importance in arthritis during mycobacterial infections, and possibly in chronic leprosyrelated arthritis. The $65 \mathrm{kDa}$ protein is an immunodominant target for T-cell responses in Hansen's disease, and shares homology with the human $60 \mathrm{kDa}$ protein. ${ }^{21}$ The response to bacterial antigens stimulates T-cell clones that may cross react with intrinsic components of the joints in susceptible individuals.

The auto-antibodies generated in Hansen's disease are considered natural antibodies with low affinity, and therefore their possible participation in the pathogenic mechanisms of chronic leprosy-related arthritis is improbable. In our study, no correlation was found between auto-antibodies and arthritis.

Although the humoral response was not considered an important mechanism for defense or for the clinical manifestations of Hansen's disease, it may indicate that B cells had been activated as part of the network of immune alterations occurring during mycobacteria recognition. In Hansen's disease, auto-antibodies are low-affinity antibodies and may only be important when forming immunocomplexes. Tubercle bacilli have been considered potent adjuvants for induction of polyclonal B lymphocytes activation. ${ }^{22}$ In addition, no cross-reaction was observed between the $70 \mathrm{kDa}$ mycobacterial protein and human structures. ${ }^{23}$ The polyclonal B-cell activation in lepromatous leprosy is probably a consequence of cytokine production by $\mathrm{T}$ lymphocytes.

Perpetuation of arthritis may be due to the persistence of antigens inside the joints or to the homing of the continually activated T lymphocytes,${ }^{24}$ as demonstrated in adjuvant arthritis and inflammatory arthritis. In particular, it has been shown that when $65 \mathrm{kDa}$ specific- $\mathrm{T}$ lymphocytes migrate to the joint, articular lymphocytes are responsible for the continuation of the immune response, mainly because these cells are memory cells. ${ }^{17.24}$ Mastocytes may also be able to amplify the response within the joint in chronic arthritis. ${ }^{25}$ In reactive arthritis, an augmented T-cell response was detected in synovialderived cells when compared to peripheral blood cells responses, demonstrating a local activation of T cells, ${ }^{18}$ or migration of chronically activated cells.

Several patients with Hansen's disease and chronic arthritis required specific treatment for the articular manifestations, such as chloroquine or sulfasalazine. ${ }^{15}$ Therapeutic results were very good and in many patients, symptoms disappeared even after drug use had been interrupted. Inhibition of the antigen presentation by chloroquine may be one of the possible mechanisms by which this drug ameliorates $\mathrm{M}$. leprae-induced arthritis.

The presence of arthritis in all types of Hansen's disease and in patients without reactions emphasizes that the contact with the bacilli may trigger chronic immunological responses in genetically predisposed individuals. Indeed, chronic synovitis was demonstrated in biopsies of patients with active Hansen's disease and during reaction, indicating that chronic inflammation may occur parallel to acute manifestations. ${ }^{26}$ POWELL and SWAN $^{27}$ also detected chronic inflammatory infiltrates and fibromatous reaction in bone tissue of Hansen's disease patients.

ROOK clarified the immunological pathways by which slow-growing bacteria may induce and perpetuate chronic arthritis, such as mycobacterial infections. ${ }^{28}$ In brief, invading bacteria activate $\mathrm{T}$ lymphocytes which release lymphokines chronically. Those lymphokines activate B lymphocytes to produce agalactosyl immunoglobulins. In addition, bacterial antigens stimulate autoreactive clones that may induce immune responses mediated by antibodies or by T-cells. It is believed that local immune responses also occur in addition to the homing of sensitized $\mathrm{T}$ lymphocytes to the joint.

Studies of the mechanisms involved in arthritic manifestation in infectious diseases may clarify the possible pathways by which chronic inflammatory diseases are induced, and suggest new therapeutical options, such as peptide-based immunotherapy. ${ }^{29}$ 


\section{ReSUMO}

A importância de agentes infecciosos na patologia humana aumentou significamente após a constatação da participação destes agentes em fenômenos auto-imunes, além da indução de processos sépticos primários. Os mecanismos pelos quais microorganismos induzem manifestaçōes de auto-imunidade, como a artrite, tem sido investigados, especialmente os que envolvem as micobactérias como agente etiopatogênico. No modelo experimental de artrite por adjuvante e em algumas doenças inflamatórias articulares humanas, por exemplo na artrite reativa, comprovou-se o envolvimento de linfócitos $T$ e em alguns casos da micobactéria no desencadeamento da artrite. Foi verificada reação cruzada entre a proteína de 65 quilodaltons (kD) de micobactéria e proteoglicanos da cartilagem, evidenciando um possivel mecanismo na produção de artrite. A ativação de células $\mathrm{B}$ foi também comprovada na doença micobacteriana humana, as quais participam, da produção crônica de citocinas ou como células apresentadoras de antigeno. Em pacientes portadores de hanseniase por nós estudados, artrite periférica de padrāo crônico, não relacionada a estados reacionais (eritema nodoso hansênico e reaçāo reversa) e em pacientes considerados com hanseníase inativa foi diagnosticada. O quadro inflamatório articular estava presente em todas as formas de hanseniase inclusive nas paucibacilares. Os mecanismos que poderiam levar à artrite crônica em pacientes com hanseniase sāo aqui discutidos.

\section{REFERENCES}

1. Pearson CM. Development of arthritis, periarthritis and periostitis in rats given adjuvants. Proc Soc Exp Biol New York 1956;95-101.

2. Torisu M, Miyahara T, Shinohara N, Ohsato K, Sonozaki H. A new side effect of BCG immunotherapy: BCG induced arthritis in man. Cancer Immunol 1978;5:77-83.

3. Lydyard PM, Rook GAW, Tsoulfa G, Sharif M, Smith M. Is there a role for mycobacteria in the etiopathogenesis of rheumatoid arthritis? Immunol Reviews 1991;121:137-54.

4. De Graeff-Meeder Er, Van Der Zee R, Rijkers GT, et al. Recognition of human $60 \mathrm{kD}$ heat shock protein by mononuclear cells from patients with juvenile chronic arthritis. Lancet 1991;337:1368-72.

5. Li SG, Quayle AJ, Shen Y, et al. Mycobacteria and human heat shock protein-specific cytotoxic $\mathrm{T}$ lymphocytes in rheumatoid synovial inflammation. Arthr Rheum 1992;35:270-81.

6. Bahr GmM Rook GAW, Al-Saffar M, Van Embden JDA, Stanford JL, Behbehani K. An analysis of antibody levels to mycobacteria in relation to HLA type: Evidence for nonHLA-linked high levels of antibody to the $65 \mathrm{kD}$ heat shock protein of M. tuberculosis in rheumatoid arthritis. Clin Exp Immunol 1989;74:211-5.

7. Van Eden W, Thole Jer, Van Der Zee R, et al. Cloning of the mycobacterial epitope recognized by $\mathrm{T}$ lymphocytes in adjuvant arthritis. Nature 1988;331:171-3.

8. Holoshitz J, Klajman A, Drucker I, et al. T lymphocytes of rheumatoid arthritis patients show augmented reactivity to a fraction of mycobacteria cross-reactive with cartilage. Lancet 1986;9:305-9.

9. Filley E, Andreoli A, Steele J, et al. A transient rise in agalactosyl IgG correlating with free IL-2 receptors during episodes of erythema nodosum leprosum. Clin Exp Immunol 1989;76:343-7.

10. Rook G. Rheumatoid arthritis, mycobacterial antigens and agalactosyl IgG. Scand J Immunol 1988;28:487-93.

11. Rook G, Lydyard P, Stanford JL. Mycobacteria and rheumatoid arthritis. Arth Rheum 1990;33(3):431-5.

12. Atkin SL, El-Ghobarey A, Kamel M, Owen JP, Dick WC. Clinical and laboratory studies of arthritis in Hansen's disease. Brit Med J 1989;298:1423-5.

13. Atkin SL, El-Ghobarey A, Kamel M, Owen JP, Dick WC. Clinical and laboratory studies in patients with leprosy and enthesitis. Ann Rheum Dis 1990;49:715-7.

14. Atkin SL, Welbury RR, Stanfield E, Beavis D, Iwais B, Dick WC. Clinical and laboratory studies of inflammatory polyarthritis in patients with leprosy in Papua New Guinea. Ann Rheum Dis 1987;46:688-90.

15. Cossermelli-Messina W. Abordagem reumatológica na hanseníase - Dissertação de Mestrado, Faculdade de Medicina da USP, 1992.

16. Whitehouse MW. Rat polyarthritis: Induction with adjuvants constituted with mycobacteria (and oils) from the environment. J Rheumatol 1992;9:494-501.

17. Gaston JSH, Life PF, Bailey LC, Bacon PA. In vitro responses to a 65 kilodalton mycobacterial protein by synovial $\mathrm{T}$ cells from inflammatory arthritis patients. J Immunol 1989;143(8):2494-500.

18. Gaston JSH, Life PA, Granfors K, et al. Synovial T lymphocyte recognition of organisms that trigger reactive arthritis. J Exp Med 1989;76:348-53.

19. Van Eden W, Holoshitz J, Nevo Z, Frenkel A, Klajman, Cohen IR. Arthritis induced by a T-lymphocyte clone that responds to mycobacterium tuberculosis and to cartilage proteoglycans. Proc Natl Acad Sci USA 1985;82:5117-20.

20. Quayle AJ, Wilson KB, Li SG, et al. Peptide recognition, Tcell receptor usage and HLA restriction elements of human 
heat-shock protein (hsp) 60 and mycobacterial 65-kDa hspreactive T-cell clones from rheumatoid synovial fluid. Eur J Immunol 1992;22:1315-1322.

21. Mculloch J, Lydard PM, Rook GAW. Rheumatoid arthritis: How do the theories fit the evidence. Clin Exp Immunol 1993;92:1-6.

22. Winfield JB. Stress proteins, arthritis, and autoimmunity. Arthr Rheum 1989;32:1497-1504.

23. Davenport MP, McKenzie KR, Basten A, Britton WJ. The variable C-terminal region of the mycobacterium leprae 70 kilodalton heat shock protein is the target for humoral immune responses. Infect Immunity 1992;60(3):1170-7.

24. Dejoy SQ, Ferguson-Chanowitz K, Oronsky AL, Zabriskie JB, Kerwar SS. Studies on the homing of mycobacterium- sensitized T-lymphocytes to the synovium during passive adjuvant arthritis. Cell Immunol 1990;130:195-203.

25. Mican JA, Metcalfe DD. Arthritis and mast cell activation. J Allergy Clin Immunol 1990;86(4):677-83.

26. Holla VV, Kenetkar MV, Kolhatkar MK, Kulkarin CN. Leprous synovitis: A study of fifty cases. Int J Lepr Mycobact Dis 1983;5:29-32.

27. Powell CS, Swan LL. Leprosy pathologic changes observed in fifty consecutive necropsies. Am J Pathol 1955;31:1131-47.

28. Rook G, Stanford JL. Slow bacterial infections or autoimmunity? Immunol Today 1992;13(5):160-4.

29. Yang XD, Gasser J, Feige U. Prevention of adjuvant arthritis in rats by a nonapeptide from the $65 \mathrm{kD}$ mycobacterial heatshock protein. Clin Exp Immunol 1990;81:189-194. 